Slawomir Organowski MD FRCPC, Peter G. Duncan MD FRCPC

\title{
Clinical differences in spinal opioid efficacy
}

The case report describes a patient who presented with two simultaneously-occurring but distinct pain syndromes. Epidural morphine controlled the pain from the abdominoperineal resection, while the pain from a deep venous thrombosis was not masked. Such differential effects of epidural morphine on pain of varying origin supports physiological observations on the specificity of the site of action of spinal opioids.

Epidural narcotics can be administered for various types of acute and chronic pain conditions. ${ }^{1-6}$ However, compared with other treatment modalities, their use is unique in that profound pain relief may be demonstrated in certain circumstances, but not in others. This case report describes a patient who presented with two simultaneously occurring but distinct pain syndromes, and who exhibited differential benefit from epidural morphine.

\section{Case report}

A 53-year-old $63 \mathrm{~kg}$ caucasian woman, a former anaesthetic nurse, was scheduled for total proctocolectomy with Koch's pouch formation. She was in good general condition despite a 15-year history of ulcerative colitis treated with steroids and nutritional supplements. Previously she had had two general anaesthetics without problems being noted. However, there was a history of thrombophlebitis complicating her multiple pregnancies. Preoperative laboratory investigation included normal haemoglobin concentration and coagulation profile.

During the preanaesthetic visit she consented to receive a balanced anaesthetic employing an epidural catheter, in concert with a general anaesthetic for comfort. She was premedicated with lorazepam $3 \mathrm{mg}$ PO and was brought to the anaesthetic induction room in a relaxed condition.

\section{Key words}

ANAESTHETIC TECHNIQUES: epidural, opiates; COMPLICATIONS: thrombosis; PAIN: postoperative; PHARMACOLOGY: narcotics, spinal; VEINS: thrombophlebitis.

From the Department of Anaesthesia, University of Saskatchewan, University Hospital Saskatoon, Saskatchewan, S7N $0 \mathrm{XO}$.

Address correspondence to: Dr. Slawomir Organowski.
After appropriate monitoring was established, an epidural catheter was placed at the $\mathrm{L}_{2-3}$ space with no blood, CSF or paraesthesia detected. The epidural catheter was advanced $4 \mathrm{~cm}$, then its position was tested with $3 \mathrm{ml}$ of 0.5 per cent bupivacaine with adrenaline 1:200,000. Conduction anaesthesia was established with incremental injections to a total dose of $25 \mathrm{ml} 0.5$ per cent bupivacaine with adrenaline 1:200,000. Anaesthesia was demonstrable to a T8 level. The patient was then taken to the operating room, anaesthesia was induced with thiopentone and her trachea was intubated with the aid of vecuronium. Anaesthesia was maintained with $\mathrm{N}_{2} \mathrm{O} / \mathrm{O}_{2}$ with one per cent halothane inspired. She was placed in the lithotomy position with $15^{\circ}$ Trendelenburg for the duration of the procedure. Since she responded to the upper abdominal incision, $\mathrm{CO}_{2}$ lidocaine with adrenaline $1: 200,000,10 \mathrm{ml}$, was injected via the epidural catheter. After $3 \frac{1}{2}$ hours, $5 \mathrm{mg}$ epidural morphine was injected. Total anaesthetic time was six hours and she was extubated awake.

In the Recovery Room the patient was given $3 \mathrm{mg}$ morphine IV for moderate discomfort. After satisfactory recovery, she was transferred to the Observation Unit for further monitoring while epidural morphine $5 \mathrm{mg} \mathrm{q} 8 \mathrm{~h}$ was employed.

The following morning the patient was alert and oriented but complained of right leg and calf pain. The right calf was swollen, tender and a positive Homan's sign was elicited. A venogram confirmed deep venous thrombosis. In spite of the findings, the surgeon elected not to anticoagulate the patient. At the same time she denied either abdominal or perineal pain. The same situation continued with respect to her pain until the third postoperative day when the epidural morphine was discontinued. On the fourth postoperative day, she developed abdominal discomfort that was effectively managed by intramuscular meperidine. Meperidine alleviated her pain from deep venous thrombosis as well. Unfortunately, the meperidine therapy was complicated by confusion and disorientation, and was discontinued. Her subsequent recovery was uneventful (Table).

\section{Discussion}

There are clinical differences in spinal opioid efficacy. This case clearly showed that epidural morphine did not mask pain from deep venous thrombosis, while at the 
same time it did provide excellent pain relief after abdominoperineal resection.

The rationale for the use of epidural opioids is based upon the theory that pain modulating systems exist at the spinal cord level. ${ }^{7-10}$ The substantia gelatinosa is particularly rich in pre- and postsynaptic opioid receptors which are stimulated in the physiological state by enkephalins. Enkephalins in tum inhibit release of substance $P$ which is a known pain neurotransmitter. ${ }^{4}$ While opioid receptors and enkephalins are also involved in pain modulation at higher levels of the central nervous system, their accessibility at the spinal cord makes their pharmacological stimulation attractive.

Little is known about the efficacy of spinal opioids in different pain syndromes, although variations are common. ${ }^{11}$ It is said that dull pain is blocked better with epidural morphine than sharp, acute pain. This may have a physiological explanation because epidural morphine has been shown to be efficacious in reducing dull pain transmitted by C" fibres and of questionable value in relieving acute, sharp pain transmitted by an "A-delta" fibres. ${ }^{9}$ One possible explanation is differential fibre stimulation related to activation of different classes of nociceptors. Alternatively, there may be a differential effect of opioids on subpopulations of opioid receptors located in the substantia gelantinosa. ${ }^{12}$ Finally, modulation at the spinal cord level of pain-coding information by bulbospinal adrenergic pathways, adenosine, neurotensin, cholinergic receptors, GABA and somatostatin has to be considered. ${ }^{12}$

In this case epidural morphine did not mask the pain from deep venous thrombosis while providing full relief from the pain due to the abdominoperineal resection. If this report is confirmed by similar observations in other patients with deep venous thrombosis, it may suggest a further advantage of epidural opiates over systemic narcotics in providing analgesia for surgical patients at risk of this complication.

In summary, this report illustrates a differential effect of epidural morphine on pain of various aetiologies occurring in a single patient, and lends support to the clinical efficacy of this technique in defined pain syndromes.

TABLE: Effects of epidural morphine $5 \mathrm{mg} \mathrm{q} 8 \mathrm{~h}$ on abdominal and calf pain.

\begin{tabular}{llllll}
\hline & OR Day & lst Day & 2nd Day & 3rd Day & 4th Day \\
\hline Epidural morphine & Yes & Yes & Yes & No & No \\
Abdominal pain & Yes & No & No & No & Yes \\
Calf pain & No & Yes & Yes & Yes & Yes \\
\hline
\end{tabular}

\section{References}

1 Bromage $P R$. The price of intraspinal narcotic analgesia. Basic constraints. Anesth Analg 1981; 60: 461-3.

2 Bromage PR. Camporesi EM, Durant PAC, Nielsen $\mathrm{CH}$. Nonrespiratory side effects of epidural morphine. Anesth Analg 1982; 61: 490-5.

3 Bromage PR. Camporesi EM, Durant PAC, Nielsen $C H$. Influence of epinephrine as an adjuvant to epidural morphine. Anesthesiology 1983; 58: 257-62.

4 Cousins MJ, Mather LE. Intrathecal and epidural administration of opioids. Anesthesiology 1984; 61: 276-310.

5 Gustaffson $L L$, Schildt $B$, Jacobsen $K$. Adverse effects of extradural and intrathecal opiates: Report of a nationwide survey in Sweden. Br J Anaesth 1982; 54: 479-85.

6 Magora $F$, Olshwang D, Eimerl $D$, Katzenelson $R$, Cotev $S$. Davidson JT. Observations on extradural morphine analgesia in various pain conditions. $\mathrm{Br} \mathrm{J}$ Anaesth 1980; 52: 247-251.

7 Hughes SC. Intraspinal opiates in obstetrics, Chapter 10. Anesthesia for Obstetrics, 2nd Edition. Shneider SM (Ed.). Levinson G. Williams and Wilkins, 1987.

8 Kitahata LM, Kosaka Y, Taub A, Bonikos K. Hoffert, $M$. Lamina-specific suppression of dorsal-horn unit activity by morphine sulfate. Anesthesiology $1974 ; 41$ : 39-47.

9 Cousins MJ, Bridenbaugh PO. Neural Blockade (2nd ed.). J.B. Lippincott Company 1988; pp. 955 -1017.

10 Covino BG, Scott DB. Handbook of Epidural Anaesthesia and Analgesia. Grune and Stratton, Inc 1985; pp. 77-80.

11 Arner S, Arner B. Differential effects of epidural morphine in the treatment of cancer-related pain. Acta Anaesthesiol Scand 1985 29: 32-6.

12 Yaksh TL, Gauman DM. Stevens CW. Receptors in the dorsal horn and intrathecal drug administration. Ann NY Acad Sci 1988; 531: 90-107.

\section{Résumé}

Voici l' histoire d' une patiente souffrant simultanément de deux types de douleur distincts. Nous avons réussi d soulager la douleur causée par une résection abdomino-périnéale du rectum avec de la morphine par voie péridurale, sans toutefois occulter la douleur associée è une thrombophlébite profonde. L'effet sélectif de la morphine péridurale sur des douleurs $d$ ' origines diverses peut trouver son explication dans l' existence de plusieurs sites d'action spécifiques au niveau rachidien. 